\title{
СУЧАСНІ ВИКЛИКИ ТА ПРОБЛЕМИ ІДЕНТИФІКАЦІї СІЛЬСЬКИХ ТЕРИТОРІЙ У НЕСПРИЯТЛИВИХ УМОВАХ В УКРAÏHI
}

\section{MODERN CHALLENGES AND ISSUES OF IDENTIFICATION OF RURAL ZONES UNDER DISADVANTAGED CIRCUMSTANCES IN UKRAINE}

\author{
Сторонянська Ірина Зеновіївна \\ доктор економічних наук, профресор, \\ ДУ «ннститут регіональних досліджень імені М.І. Долішнього \\ Національної академії наук України» \\ ORCID: https://orcid.org/0000-0002-0237-1409 \\ Залуцький Іван Романович \\ кандидат економічних наук, доцент, \\ ДУ «Інститут регіональних досліджень імені М.І. Долішнього \\ Національної академії наук України» \\ ORCID: https://orcid.org/0000-0002-3652-1145 \\ Патицька Христина Олегівна \\ кандидат економічних наук, \\ ДУ «Інститут регіональних досліджень імені М.І. Долішнього \\ Національної академії наук України» \\ ORCID: https://orcid.org/0000-0003-2871-7540
Storonianska Iryna, Zalutskyi Ivan, Patytska Khrystyna
State Institution «M.I. Dolishniy Institute of Regional Research of the National Academy of Sciences of Ukraine»

\begin{abstract}
Стаття присвячена актуальним питанням ідентифікації сільських територій у несприятливих умовах в Україні. Проаналізовано підхід до визначення сільських територій у несприятливих умовах, застосований у Державній стратегії регіонального розвитку на 2021-2027 роки. Аргументовано і доведено доцільність врахування економічного чинника, поруч із демографічними та просторовими, для охоплення ширшого кола проблем, з якими стикаються територіальні громади в процесі свого розвитку. Здійснено аналіз диспропорцій соціально-економічного та демографрічного розвитку сільських територій. На основі отриманих результатів доведено потребу узгодження адміністративно-територіального рівня, на якому ідентифікація сільських територій у несприятливих умовах повинна здійснюватися з метою врахування внутрішньорегіональних відмінностей та особливостей розвитку територій.
\end{abstract}

Ключові слова: переважно сільські території у несприятливих умовах, регіональний розвиток, ідентифрікація, економічний чинник, демограсрічний фрактор, просторовий аспект.

Статья посвящена актуальным вопросам идентификации сельских территорий в неблагоприятных условиях Украины. Проанализирован подход к определению сельских территорий в неблагоприятных условиях, примененный в Государственной стратегии регионального развития на 2021-2027 годы. Аргументирована и доказана целесообразность учета экономического фрактора, наряду с демограсрическими и пространственными, для охвата более широкого круга проблем, с которыми сталкиваются территориальные общины в процессе своего развития. Осуществлен анализ диспропорций социально-экономического и демографического развития сельских территорий. На основе полученных результатов доказана необходимость согласования административно-территориального уровня, на котором идентификация сельских территорий в неблагоприятных условиях должна осуществляться с учетом внутрирегиональных различий и особенностей развития территорий.

Ключевые слова: преимущественно сельские территории в неблагоприятных условиях, региональное развитие, идентифрикация, экономический фрактор, демографрический фрактор, пространственный аспект. 
The article is devoted to topical issues of identification of rural areas in unfavorable conditions in Ukraine. The approach to the definition of rural areas in adverse conditions, applied in the State Strategy for Regional Development for 2021-2027, is analyzed. This approach takes into account the criteria of population density, distance from cities with a population of more than 50 thousand people and population reduction over a long period of time. The problems of uneven distribution of the population on the territory of Ukraine are substantiated and the peculiarities of territorial localization of the settlement network are emphasized, which requires taking into account the reverse influence of the socio-economic situation on the processes of depopulation and changes in territorial distribution. In this context, the expediency of taking into account the economic factor (in particular, tax revenues of local budgets per capita, the number of legal entities and their change in time), along with demographic and spatial, to cover a wider range of problems faced by local communities in in the process of its development. It is established that the problems of depopulation concern the east and the northeast, and economic risks are inherent in the territories of the west of Ukraine. Therefore, for the effective identification of mainly rural areas in adverse conditions, taking into account the economic factor of territorial development is appropriate, because it allows to cover a wider range of criteria. The analysis of disparities of socio-economic and demographic development of rural areas was carried out separately. The comparison of the regions of Ukraine, which are referred to the category of mostly rural, with the largest and smallest values of individual indicators. The ratio of indicators of socio-economic development of mainly rural areas at the intra-regional level has been studied. Based on the obtained results, the need for coordination of the administrative-territorial level is proved, at which the identification of rural areas in unfavorable conditions should be carried out in order to take into account intra-regional differences and peculiarities of territorial development.

Keywords: mainly rural areas in unfavorable conditions, regional development, identification, economic factor, demographic factor, spatial aspect.

Постановка проблеми. у Державній стратегії регіонального розвитку на 2021-2027 рр. (далі - Стратегія) [1] визначено, що до сільських територій у несприятливих умовах відносяться територіальні громади, які одночасно мають такі характеристики: густоту сільського населення нижчу 15 осіб на км²; відстань до найближчих міст 3 населенням більше 50 тис. осіб понад 30 хвилин на автомобілі; більше ніж 30\% скорочення чисельності населення впродовж десятиліття, у 2008-2018 рр. Очевидно, що основний акцент у процесі ідентифрікації сільських територій у несприятливих умовах зроблено на демограсрічних та просторових характеристиках. Як наголошено у Стратегії, демограсрічна криза в перспективі матиме негативний вплив на економічну сореру через зменшення обсягу внутрішнього ринку і чисельності робочої сили, а несприятливі демограсрічні зміни уже на сучасному етапі зумовлюють трансорормації на ринку праці та зміни у структурі економіки [1].

Однак запропонований у Стратегії підхід не враховує: по-перше, історично зумовленої нерівномірності розміщення населення по території України, по-друге, особливостей територіальної локалізації мережі поселень, по-третє, зворотного впливу соціально-економічної ситуації на прочеси депопуляції та зміни територіального розподілу населення, що не сприяє ефективному та цілісному визначенню сільських територій, які перебувають у несприятливих умовах та потребують державної підтримки.
Аналіз останніх досліджень і публікацій. Проблеми соціально-економічного розвитку сільських територій у своїх наукових працях розглядають багато вітчизняних дослідників, серед яких: М. Барановський, В. Борщевський, О. Булавка, В. М. Геєць, Ю. Губені, В. Збарський, Т. Заяць, Ю. Лупенко, М. Малік, М. Могилова, М. Орлатий, О. Павлов, І. Прокопа, В. Терещенко, М. Хвесик, К. Якуба та інші. Водночас в умовах прийняття Державної стратегії регіонального розвитку на 2021-2027 рр. вектор державної регіональної політики спрямовано на визначення окремих типів територій, яким притаманні специфрічні соціальні, просторові, екологічні й економічні особливості [1; 2]. Відтак актуалізується потреба ефрективної ідентифрікації переважно сільських територій (ПСТ) у несприятливих умовах.

3 огляду на це, мета статті - здійснити проблемно орієнтований аналіз та визначити виклики і ризики ідентифрікації сільських територій у несприятливих умовах в Україні.

Виклад основного матеріалу дослідження. Аналізуючи густоту населення на ПСТ України, можна зауважити неоднорідність його розміщення (рис. 1) та нерівномірність зміни чисельності населення.

Середній показник густоти населення станом на 1 січня 2020 р. по ПСТ України становить 32,4 ос.//м². У західних та центральних областях густота населення на ПСТ вища порівняно зі східними та південними регіонами, зокрема, виявлено такі тенденції: 1) найвищою щільністю населення на ПСТ 


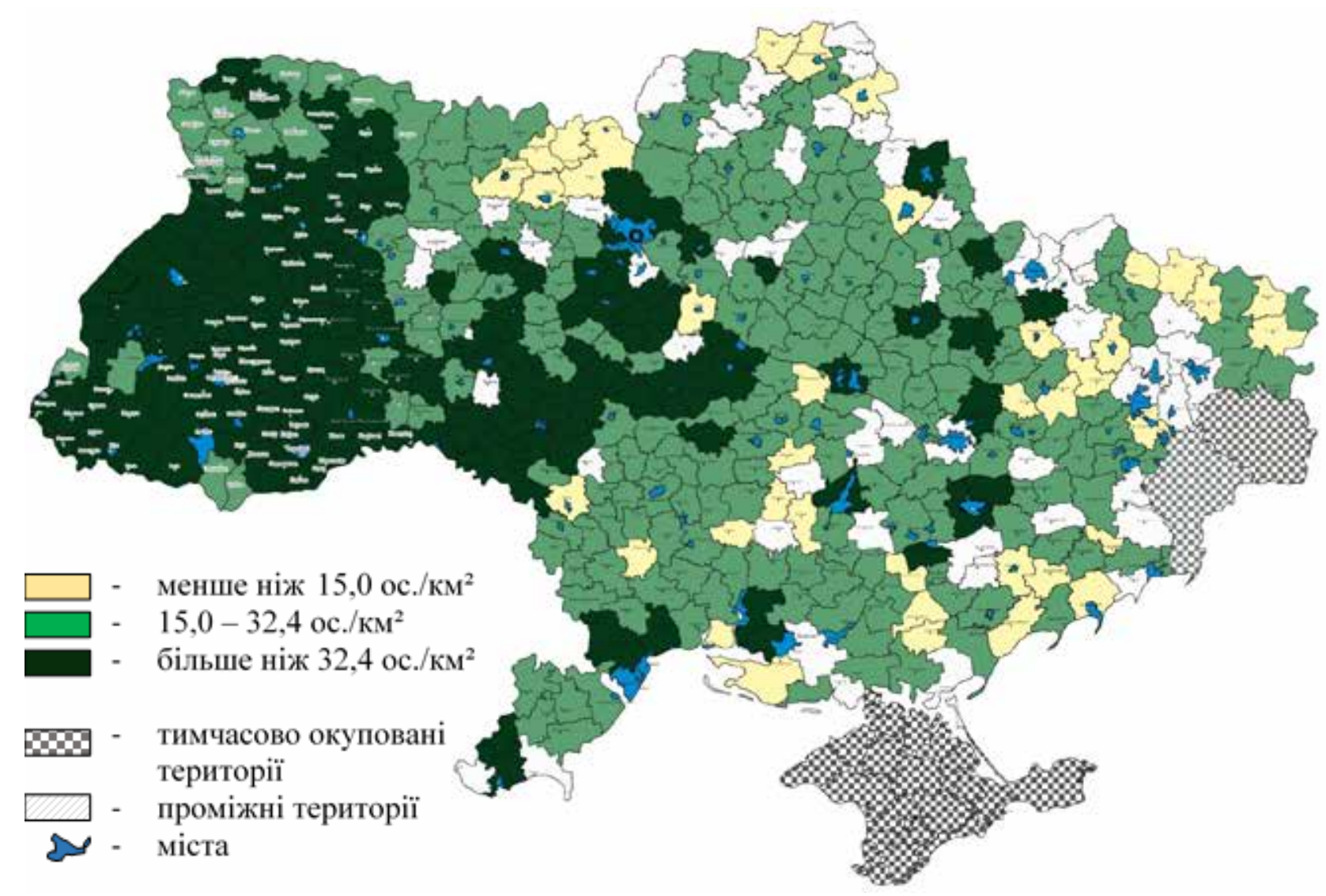

Рис. 1. Густота наявного населення переважно сільських територій України станом на 01.01.2020 p.

Джерело: складено на основі даних Державної служби статистики України

характеризуються Чернівецька $(81,7$ ос./км²), Закарпатська $(78,7$ ос./км²), Івано-Франківська $(74,6$ ос./км²) та Львівська $(66,5$ ос./км²) області; 2) найнижчою густотою населення: по-перше, території Луганської (17,3ос./км²) і Донецької (19,6 ос./км²) областей, на яких впродовж семи років, починаючи 32014 р., тривають воєнні дії, що призвело до значних міграцій населення 3 регіону; по-друге, Чернігівська $(17,6$ ос./км²) і Сумська $(19,2$ ос./км²) області, де протягом усього періоду незалежності України спостерігалося значне скорочення чисельності населення (на $40 \%$ у Чернівецькій, на 32\% у Сумській області за період 1990-2015 рр.) [3]; по-третє, порівняно низька густота населення у Миколаївській (20,0 ос.l км²), Херсонській (20,0 ос./км²), Кіровоградській (20,7 ос./км²) та Запорізькій $(21,4$ ос./км²) областях.

Основними демограсрічними проблемами в Україні $є$ депопуляція та старіння населення. За період 1991-2019 рр. чисельність наявного населення (за оцінками) скоротилася на понад 10 млн осіб [4]. Згідно з результатами досліджень науковців Інституту демографрії та соціальних досліджень імені В. М. Птухи НАН України [4] та Світового банку [5], скорочення чисельності населення впродовж 1991-2015 рр. відбувалося стрімкіше у східних регіонах України, ніж у західних та центральних областях.

Утім, аналіз зміни середньорічної чисельності наявного населення на ПСТ України за останні роки, у короткостроковому періоді 2017-2019 рр. (рис. 2), не дозволив підтвердити такі тенденції. Натомість встановлено, що процеси депопуляції населення охопили усю територію країни: у середньому чисельність населення у районах України за рік зменшується на 305,1 особи.

Зменшення середньорічної чисельності наявного населення спостерігалося у 393 із 416 районів переважно сільського типу території. Причому у західних та центральних областях темпи скорочення населення вищі порівняно з рештою країни, адже 15 з 33 ПСТ субрегіонального рівня 3 показником зменшення середньорічної чисельності наявного населення, який вдвічі перевищує середньоукраїнський рівень (понад 610,2 ос.), знахо- 
дяться у Вінницькій, Тернопільській та Хмельницькій областях.

Збільшення середньорічної чисельності наявного населення характерне лише для 23 районів в Україні, переважна більшість яких межують 3 великими містами 3 потужними соціальним та економічним потенціалом, а відповідно є міграційно привабливими. Так, із 23 районів, у яких відбулося збільшення населення, 18 розташовані поряд із містамиобласними центрами, два - із містами обласного значення.

що ж до іншого критерію ідентифрікації сільських територій у несприятливих умовах - відстані до найближчих міст з населенням більше 50 тис. осіб (які, як правило, $€$ центрами надання послуг), - то він також не дозволяє однозначно оцінити внутрішній потенціал території до розвитку. По-перше, дослідження ролі міст обласного значення як центрів соціально-економічної активності в регіоні вказують на те, що не усі міста, попри достатньо високі показники соціального розвитку, генерують позитивні імпульси на економічний розвиток прилеглих територій
[6]. По-друге, відсутність на заході країни, де сфрормувалася щільна поселенська мережа, територій із низькою густотою населення не свідчить про відсутність ризиків і загроз для їх розвитку, а є результатом історично обумовлених процесів. 3 метою врахування цих аспектів у контексті визначення ПСТ у несприятливих умовах виникає потреба аналізу економічних показників розвитку території. Вагомими показниками, які вказують на рівень економічної активності на певній території, $є$ податкові надходження місцевих бюджетів на одну особу, кількість юридичних осіб та їх зміна у часовому вимірі (рис. 3).

Аналізуючи податкові надходження в розрізі районів, які віднесено до категорії ПСТ, можна зауважити, що середній обсяг цих доходів на одну особу у 1,5 рази менший ніж середнє значення цього показника по місцевих бюджетах України (6456,6 грн.) і становить 4370,6 грн. Найвищими обсягами податкових надходжень на особу характеризуються ПСТ Київської (8053,0 грн.; понад 80\% ПСТ субрегіонального рівня регіону мають податкові надходження на особу вищі ніж середнє

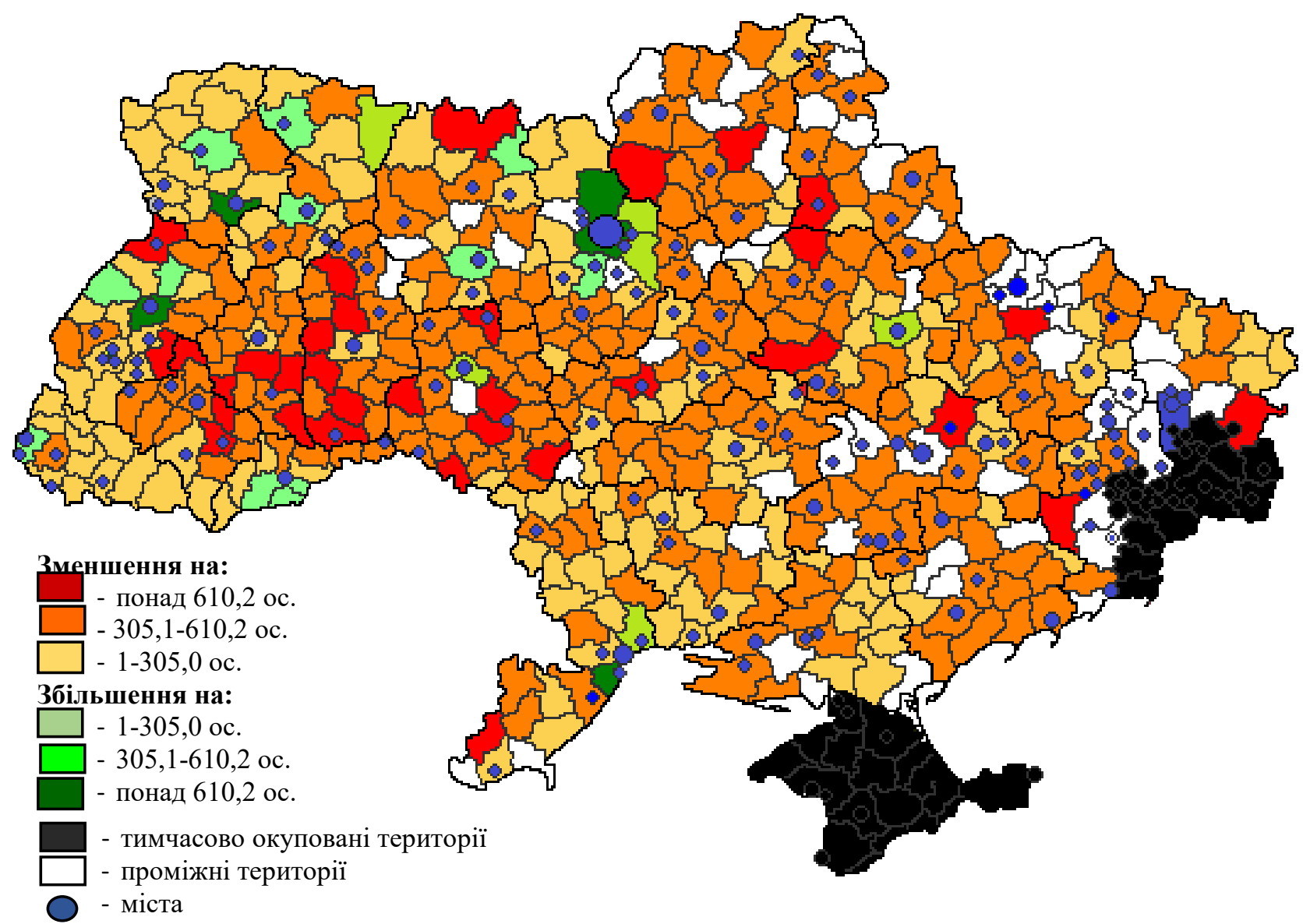

Рис. 2. Зміна середньорічної чисельності наявного населення України за 2017-2019 рр. Джерело: складено на основі даних Державної служби статистики України 


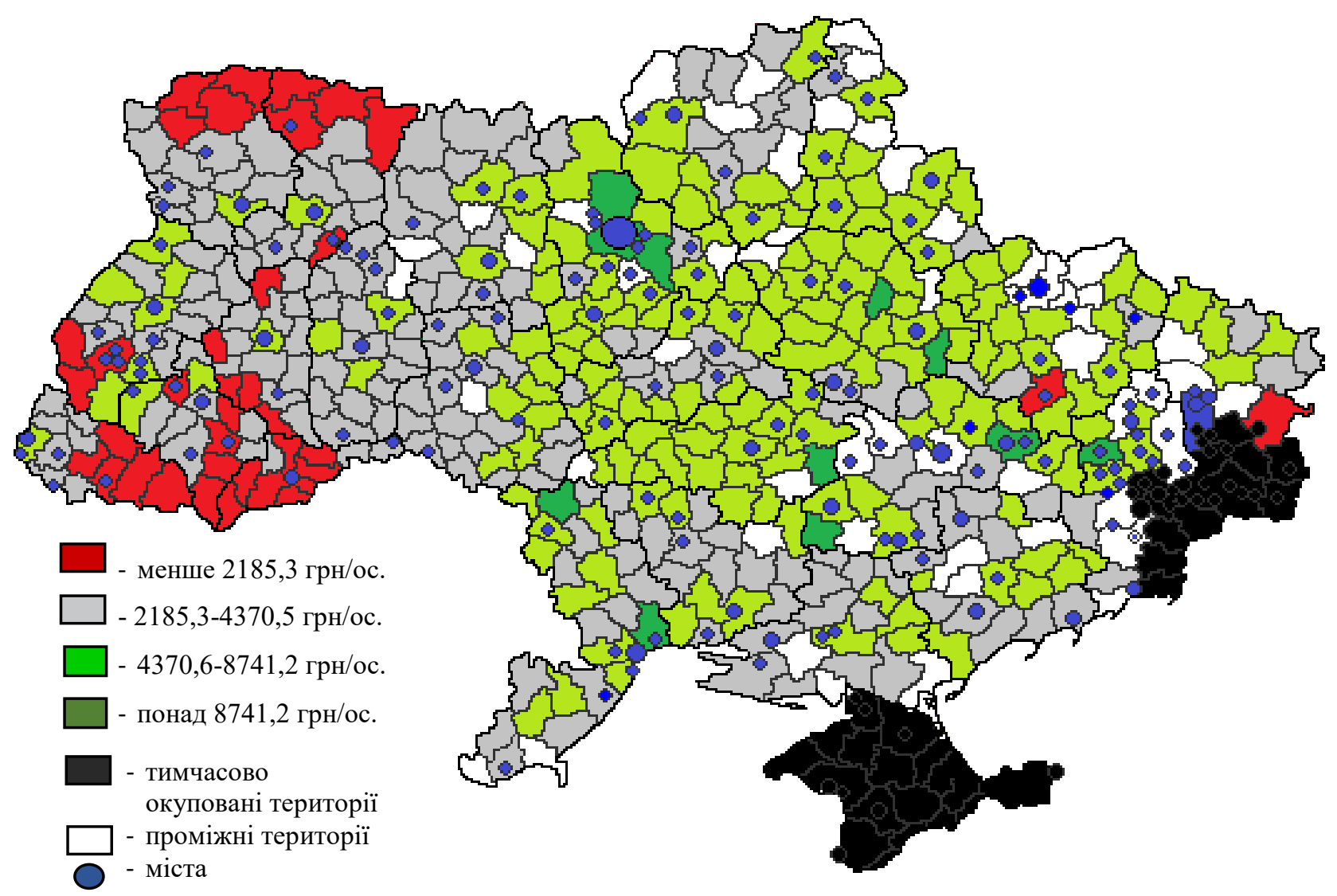

Рис. 3. Обсяг податкових надходжень зведених місцевих бюджетів районів України, які віднесено до категорії ПСТ, на одну особу, 2019 р.

Джерело: складено на основі даних Державної служби статистики України

по Україні), Полтавської (6215,1 грн.; 91,3\% районів, які віднесено до ПСТ), Дніпропетровської (5536,7 грн.; близько 65\% районів) та Кіровоградської (5518,4 грн.; 94,7\% ПСТ субрегіонального рівня) областей. Найнижчими - областей заходу України - Чернівецької (2005,4 грн.), Закарпатської (2343,7 грн.), Івано-Франківської (2509,0 грн.), Тернопільської (2807,1 грн.), Рівненської (2892,6 грн.) та Волинської (2908,9 грн.). Примітно, що до ПСТ з критичними показниками податкових надходжень на особу (більше ніж удвічі нижчими ніж середнє по ПСТ України - менше 2185,3 грн.) віднесено 36 районів, з яких 35 у західних регіонах (зокрема, понад 70\% ПСТ Чернівецької області, понад 1/3 ПСТ Закарпатської, Івано-Франківської, Тернопільської та Рівненської областей, а також окремі райони Волинської і Львівської областей).

Графрічна візуалізація результатів аналізу кількості юридичних осіб в розрізі ПСТ субрегіонального (районного) рівня (рис. 4) дозволила виявити такі тенденції:

1) концентрацію юридичних осіб у районах навколо міст-обласних центрів, які $\epsilon$ потужними економічними центрами (Києва та Житомира, Львова, Одеси, Полтави, у районах Дніпропетровської, Запорізької та Кіровоградської областей);

2) порівняно нижчу кількість юридичних осіб на 10 тис. населення у західних регіонах (Чернівецькій, Закарпатській, Івано-Франківській, Рівненській та Волинській областях), Миколаївській і Чернігівській областях.

Водночас, аналізуючи зміну кількості юридичних осіб впродовж останніх років (2017-2019 рр.) (рис. 5), бачимо, що у більшості районів, які віднесено до ПСТ, відбувається їх збільшення (середнє зростання по країні становить 4,7\%), причому найстрімкіше нові юридичні особи реєструються в ІваноФранківській, Львівській, Київській областях, а також у приморських районах на узбережжі Чорного моря, де розташовано потужні морські порти.

Зменшення кількості юридичних осіб спостерігається у 68 районах із 416 переважно сільських (16,3\%). Найбільше - у Чернігівській області (у понад 50\% районів, які віднесено до ПСТ). 


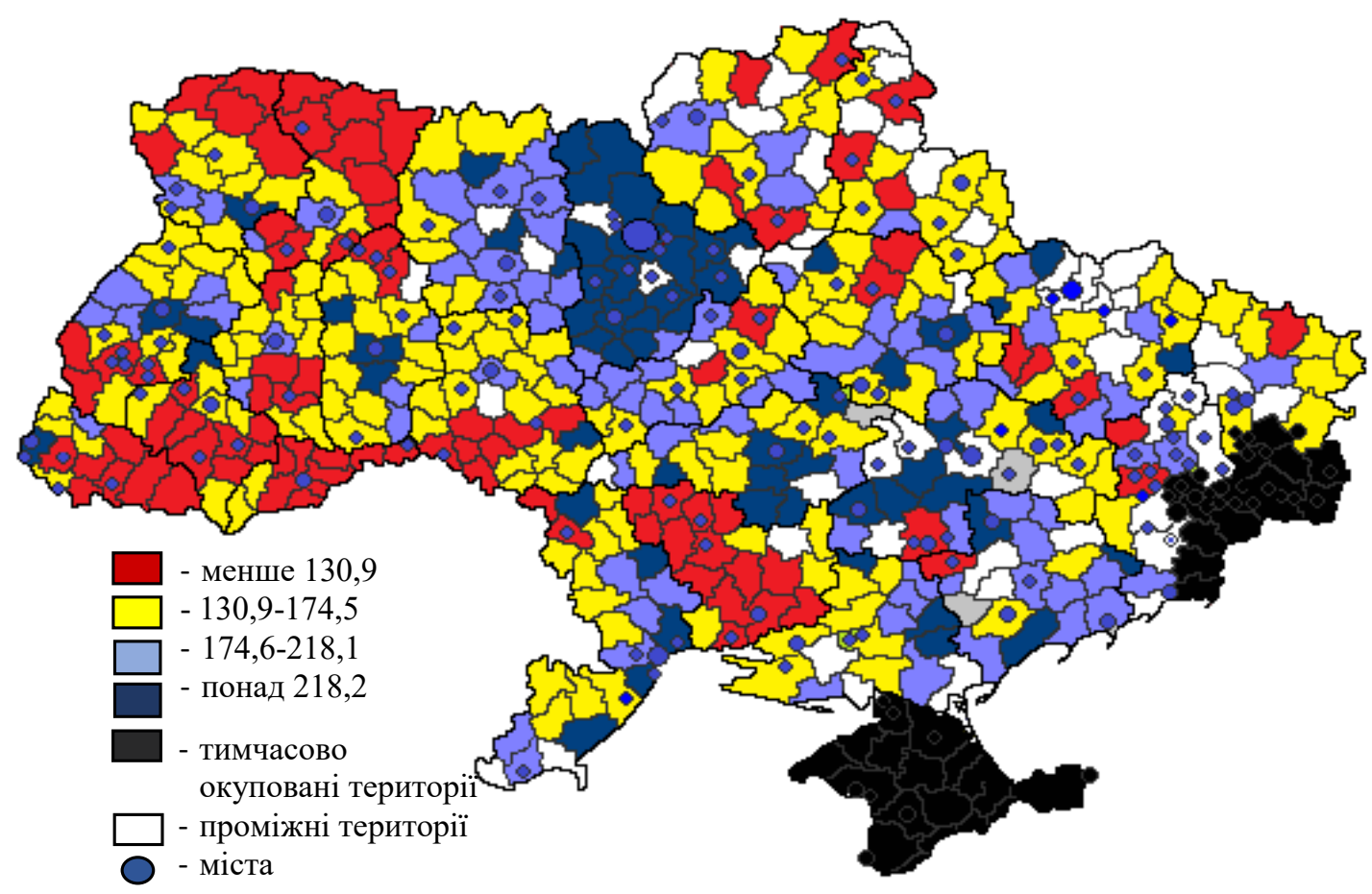

Рис. 4. Кількість юридичних осіб по районах України, які віднесено до категорії ПСт, 2019 р., од. на 10 тис. населення

Джерело: складено на основі даних Державної служби статистики України

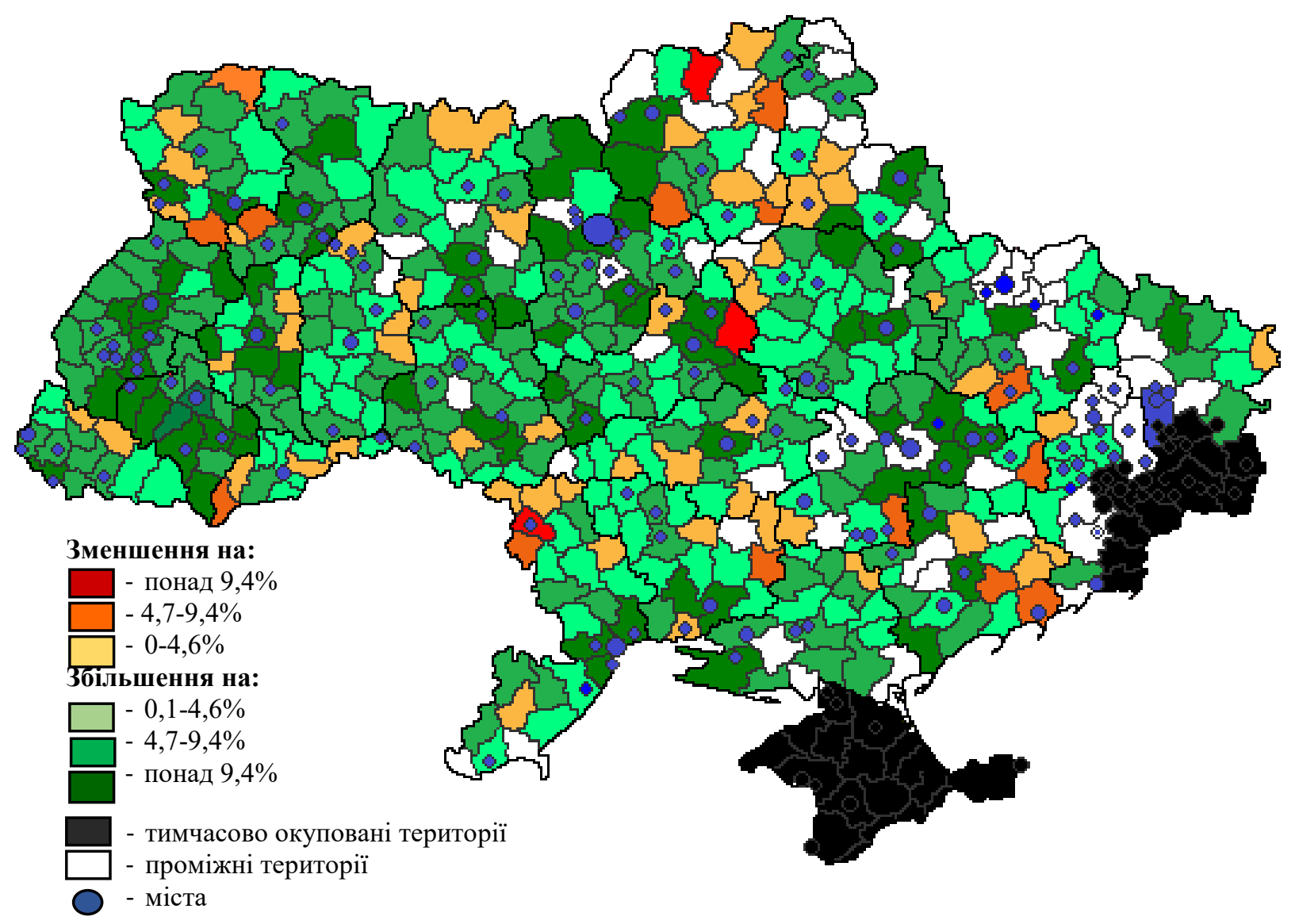

Рис. 5. Зміна кількості юридичних осіб у районах України, які віднесено до категорії ПСТ, у 2017-2019 рр., \%

Джерело: складено на основі даних Державної служби статистики України 


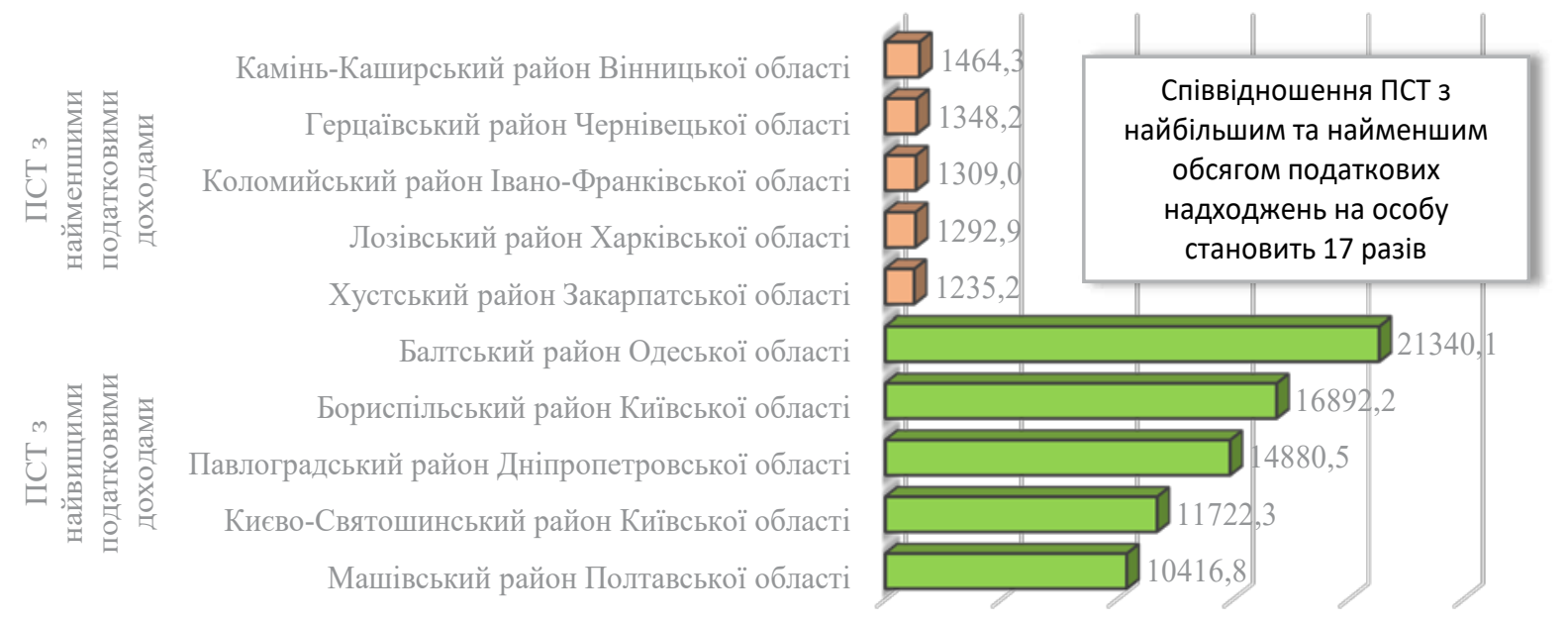

$0,0 \quad 5000,0 \quad 10000,0 \quad 15000,0 \quad 20000,0 \quad 25000,0$ ГРН

А) за обсягом податкових надходжень на одну особу

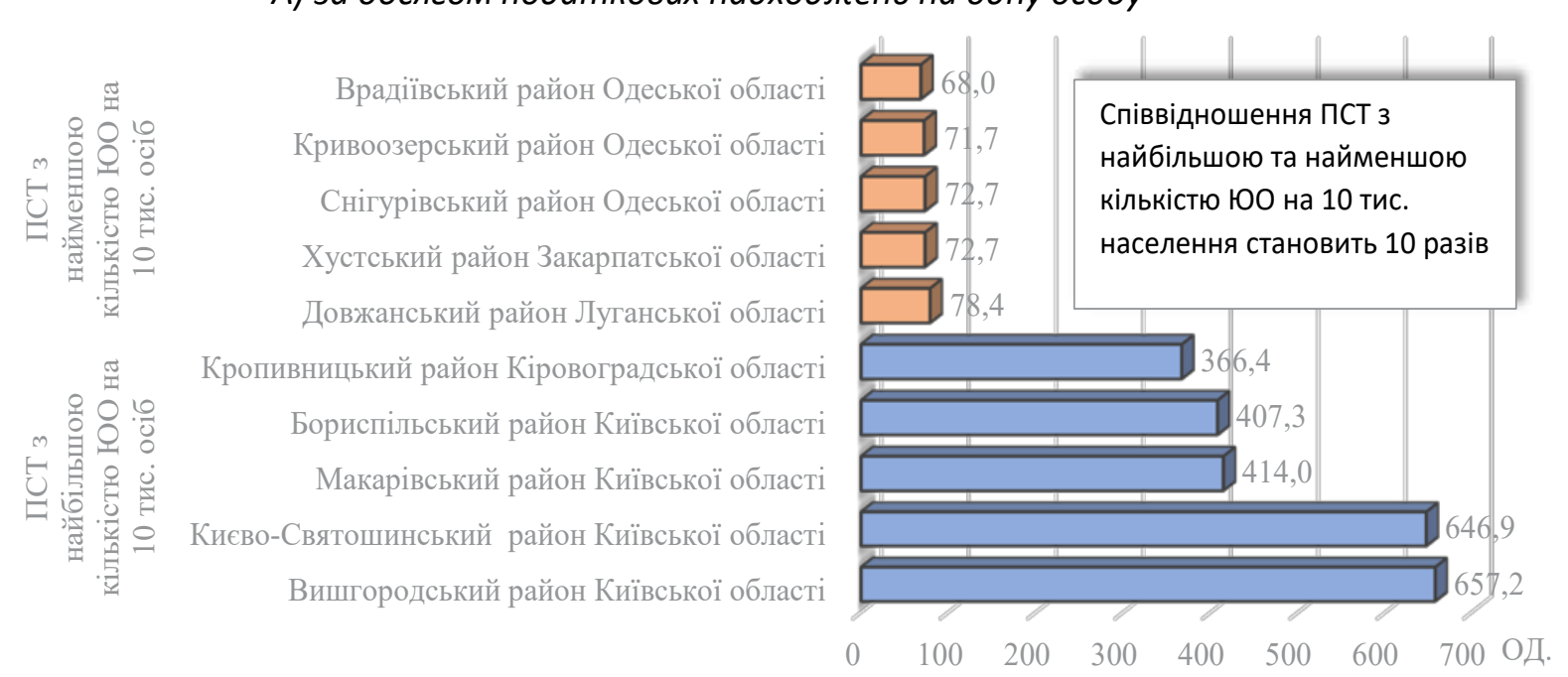

Б) за кількістю ЮО на 10 тис. населення

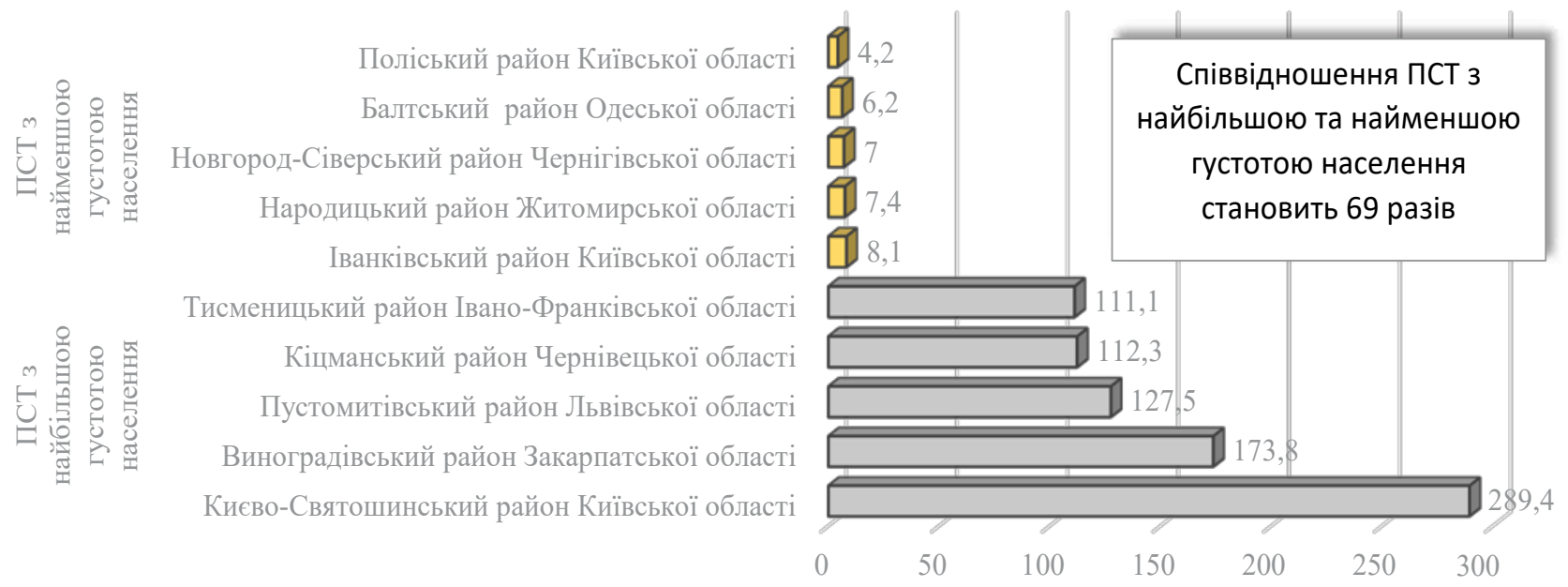

В) за густотою населення

OC./KB. KM

Рис. 6. Порівняння районів України, які віднесено до категорії ПСТ, 3 найбільшими та найменшими значеннями окремих показників, 2019 р.

Джерело: складено на основі даних Державної служби статистики України 
Узагальнюючи, здійснивши оцінку фрінансово-економічних критеріїв розвитку ПСТ в Україні, виявлено загрози економічного характеру у районах західних регіонів України та обґрунтовано такі тенденції. По-перше, центрами концентрації економічного ресурсу в Україні є Київська, Дніпропетровська, Полтавська, Запорізька, Одеська, Харківська області. Натомість низькі показники надходжень податків на одну особу та порівняно невисоку кількість юридичних осіб на 10 тис. населення виявлено у ПСТ західних регіонів (Чернівецькій, Закарпатській, Івано-Франківській, Тернопільській, Рівненській, Волинській областях) та у Чернігівській області. Це передбачувані результати аналізу, адже ці регіони суттєво відстають від середнього по Україні значення за показниками ВРП, середньомісячної заробітної плати, кількістю юридичних осіб тощо, а окремі 3 них відносяться до аутсайдерів за рівнем соціально-економічного розвитку. Така ситуація відображається і на становищі територіальних громад в цих областях, переважна більшість 3 яких характеризується вищим рівнем дотаційності у порівнянні з середнім по Україні значенням. По-друге, спостерігається концентрацію фрінансово-економічного потенціалу у ПСТ навколо міст обласного значення, які $€$ потужними соціальними й економічними центрами, зокрема навколо Києва та Житомира, Львова, Одеси, Полтави, у районах Дніпропетровської, Запорізької та Кіровоградської областей.
3 проведеного аналізу можна зробити висновок: якщо проблеми депопуляції стосуються передовсім сходу та північного сходу, то економічні ризики притаманні для територій заходу країни. Тому для здійснення ефективної ідентифрікації ПСТ у несприятливих умовах врахування економічного чинника розвитку територій є доцільним поруч із демографрічним та просторовим аспектами, адже дозволяє охопити більш широке коло критеріїв.

Ще одним вагомим чинником ефективної ідентифікації ПСТ у несприятливих умовах $€$ рівень, на якому вона повинна здійснюватися (рис. 6).

У результаті аналізу показників розвитку України на субрегіональному (районному) рівні, встановлено: 1) співвідношення ПСТ 3 найбільшим та найменшим обсягом податкових надходжень на особу становить 17 разів; 2) співвідношення ПСТ з найбільшою та найменшою кількістю ЮО на 10 тис. населення становить 10 разів; 3) співвідношення ПСТ 3 найбільшою та найменшою густотою населення становить 69 разів.

Натомість порівняння цих показників на внутрішньорегіональному рівні в Україні (рис. 7) дозволило визначити, що в середньому обсяг податкових надходжень у регіоні коливається в межах 3,1 разу між районом із найбільшим і найменшим значенням, кількістю юридичних осіб - 2,5 разу, густоти населення $-3,9$ разу. Найбільшою різницею за

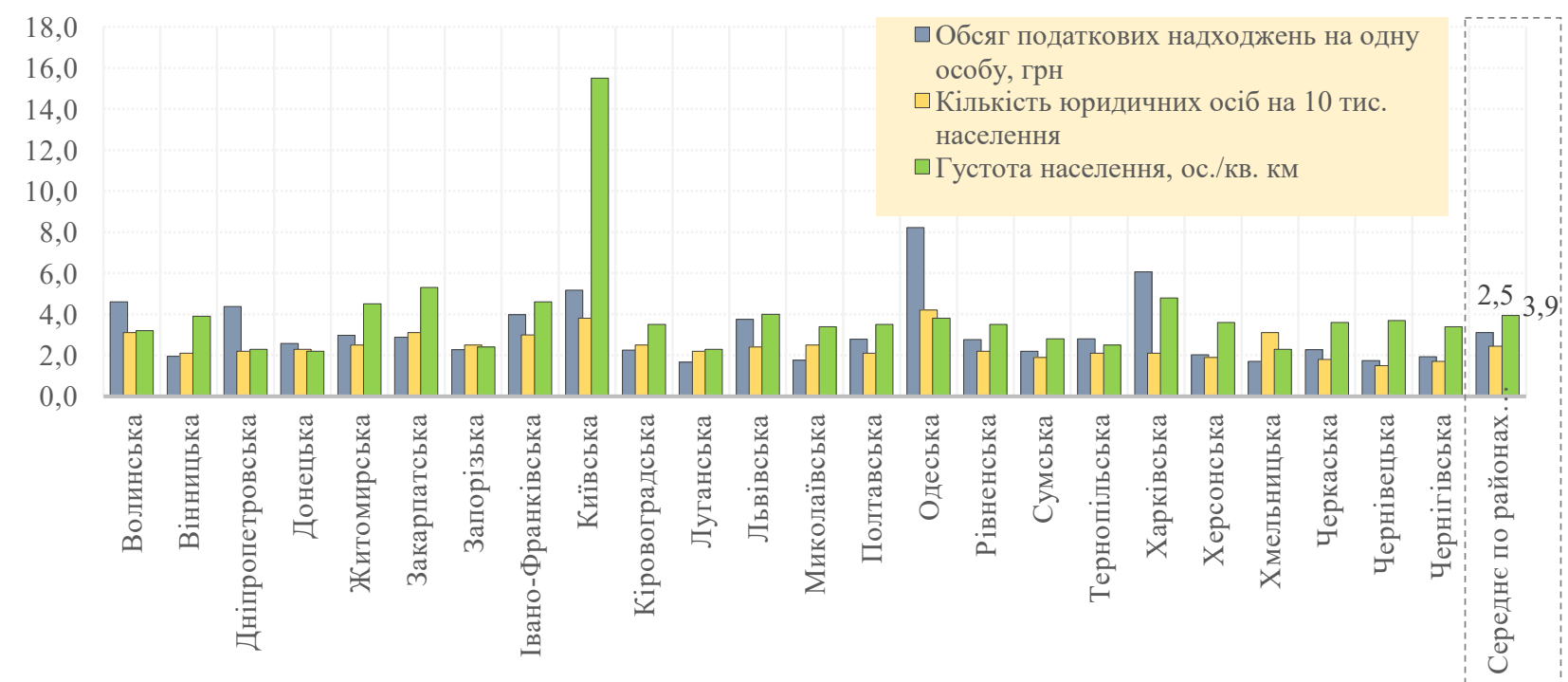

Рис. 7. Співвідношення показників соціально-економічного розвитку ПСТ України на внутрішньорегіональному рівні, 2019 рр., разів

Джерело: складено на основі даних Державної служби статистики України 
показниками податкових доходів та кількості юридичних осіб характеризується Одеська (8,2 та 4,2 разів), за густотою населення (15,5 разів) - Київська область, що пов'язано із розміщенням на території області Чорнобильської зони відчуження.

Таким чином, результати проведеного аналізу вказують на те, що пріоритизація демографрічних та просторових характеристик в умовах визначення сільських територій, які перебувають у несприятливих умовах та потребують державної підтримки, не дозволяє забезпечити бажаного ефекту та веде до неврахування інших вагомих чинників.
3 огляду на це, вважаємо, що забезпечення ефективної ідентифрікації ПСТ у несприятливих умовах можливе за двох умов: 1) шляхом проведення комплексної діагностики розвитку територій та врахування, поруч із демографічними та просторовими, економічного чинника для охоплення ширшого кола проблем, з якими стикаються територіальні громади в процесі свого розвитку; 2) узгодження адміністративно-територіального рівня, на якому така ідентифікація за певними критеріями повинна здійснюватися, з метою врахування внутрішньорегіональних відмінностей та особливостей розвитку територій.

\section{СПИСОК ВИКОРИСТАНИХ ДЖЕРЕЛ:}

1. Державна стратегія регіонального розвитку на 2021-2027 роки : Постанова Кабінету Міністрів України від 5 серпня 2020 р. № 695. URL: https://zakon.rada.gov.ua/laws/show/695-2020-\%D0\%ВF\#Техt (дата звернення: 15.09.2021).

2. Функціональні типи територій як об'єкт державної регіональної політики: методичні підходи до ідентифрікації : науково-аналітична доповідь / наук. ред. д.е.н., профр. Сторонянська І. З. Львів : ІРД НАНУ, 2020.151 с.

3. Трансформація сільського розселення в Україні : колективна монографрія / за ред. Т. А. Заяць. Інститут демографрії та соціальних досліджень імені М. В. Птухи НАН України. Київ, 2017. 298 с.

4. Населення України за 2019 рік. Демографічний щорічник. Державна служба статистики України. 2019. URL: http://www.ukrstat.gov.ua/druk/publicat/kat_u/2020/zb/10/zb_nas_2019.pdf (дата звернення: 27.09.2021).

5. Україна. Огляд урбанізації. Міжнародний банк реконструкції та розвитку / Світовий банк. Вашингтон, 2015. 218 c.

6. Патицька Х. О., Бас-Юрчишин М. А., Гринчишин І. М., Лещух І. В., Максименко А. О. Центро-периферійні взаємодії у регіоні в умовах децентралізації: ідентифікація та методичні підходи до оцінювання : науково-аналітична доповідь / НАН України. ДУ «Інститут регіональних досліджень імені М. І. Долішнього НАН України». Львів, 2020. 85 с.

\section{REFERENCES:}

1. Derzhavna stratehiya rehional'noho rozvytku na 2021-2027 roky [State strategy of regional development for 2021-2027]. Available at: https://zakon.rada.gov.ua/laws/show/695-2020-\%D0\%BF\#Text (accessed 15 September 2021).

2. Storonyans'ka I. Z. (2020) Funktsional'ni typy terytoriy yak ob"yekt derzhavnoyi rehional'noyi polityky: metodychni pidkhody do identyfikatsiyi: naukovo-analitychna dopovid' [unctional types of territories as an object of state regional policy: methodical approaches to identification: scientific-analytical report]. IRD NASU, 151 p.

3. T. A. Zayats' (2017) Transformatsiya sil's'koho rozselennya v Ukrayini: kolektyvna monohrafiya [Transformation of rural settlement in Ukraine: collective monograph]. M.V. Ptukha Institute of Demography and Social Research of the National Academy of Sciences of Ukraine. Kyiv, 20298 p.

4. Naselennya Ukrayiny za 2019 rik [The population of Ukraine in 2019]. Available at: http://www.ukrstat.gov.ua/ druk/publicat/kat_u/2020/zb/10/zb_nas_2019.pdf (accessed 27 September 2021).

5. Ukrayina. Ohlyad urbanizatsiyi [Ükraine. Review of urbanization]. International Bank for Reconstruction and Development / World Bank. Washington, 2015. 218 p.

6. Patyts'ka KH. O., Bas-Yurchyshyn M. A., Hrynchyshyn I. M., Leshchukh I. V., Maksymenko A. O. (2020) Tsentro-peryferiyni vzayemodiyi u rehioni v umovakh detsentralizatsiyi: identyfikatsiya ta metodychni pidkhody do otsinyuvannya [Centro-peripheral interactions in the region in the conditions of decentralization: identification and methodical approaches to evaluation]. NAN Ukrayiny. DU «Instytut rehional'nykh doslidzhen' imeni M. I. Dolishn'oho NAN Ukrayiny». L'viv, 85 p. 